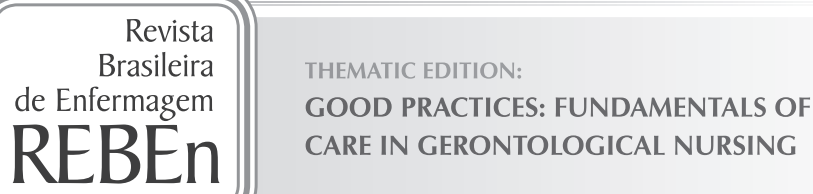

\title{
Therapeutic nursing care: transition in sexuality of the elderly caregiving spouse
}

\author{
Cuidado terapêutico de enfermagem: transições da sexualidade do cônjuge-cuidador do idoso
}

Cuidados terapéuticos de enfermería: transiciones de la sexualidad del cónyuge cuidadores de ancianos

\section{Claudia Feio da Maia Lima', Célia Pereira Caldas", Iraci dos Santos", Liana Amorim Correa Trotte"', Bárbara Martins Corrêa da Silva"}

\author{
'Universidade Federal do Recôncavo da Bahia, Center for Health Sciences, School of Nursing. \\ Santo Antônio de Jesus, Bahia, Brazil. \\ "Universidade do Estado do Rio de Janeiro, School of Nursing, Postgraduate Program in Nursing. Rio de Janeiro, Brazil. \\ II' Universidade Federal do Rio de Janeiro, School of Nursing Anna Nery, \\ Department of Nursing Methodology. Rio de Janeiro, Brazil.
}

\section{How to cite thisarticle:}

Lima CFM, Caldas CP, Santos I, Trotte LAC, Silva BMC. Therapeutic nursing care: transition in sexuality of the elderly caregiving spouse. Rev Bras Enferm [Internet]. 2017;70(4):673-81. [Thematic Edition “Good Practices: Fundamentals of care in Gerontological Nursing"] DOI: http://dx.doi.org/10.1590/0034-7167-2016-0256

Submission: 06-24-2016

Approval: 02-05-2017

\section{ABSTRACT}

Objective: To understand the transitions experienced, and the conditions and expected response patterns to changes in sexuality of the spouse-caregiver of the elderly, during progression of the dementia process. Method: A qualitative research study, conducted at the neurogeriatric clinic between May of 2014 and May of 2015. An intensive, individual interview was administered to 12 elderly caregivers. Thematic content analysis was applied, using the theoretical model of Transition Theory. Results: Seven categories emerged, involving relationship and conjugal sexuality; disease repercussions; care and professional approach; attitudes, beliefs and social imagery of sexuality and care; family relationship and redefining of sexuality. Final considerations: Family development and marital life, the aspects of formation and development of sexuality, the specifics that involved living and caring for the other were understood, with successive events and changes influenced by old age, dementia, beliefs and social imagery.

Descriptors: Dementia; Nursing Theory; Sexuality; Nursing Care; Elderly.

\section{RESUMO}

Objetivo: compreender as transições vivenciadas, suas condições e os padrões de resposta esperados a mudanças na sexualidade do cônjuge-cuidador do idoso em processo demencial. Método: pesquisa de abordagem qualitativa, realizada no ambulatório de neurogeriatria, entre maio de 2014 e maio de 2015. Aplicou-se a entrevista individual e intensiva a 12 cônjuges-cuidadores de idosos. Fezse a análise de conteúdo temática, com aplicação do modelo teórico da Teoria das Transições. Resultados: emergiram sete categorias, que envolveram relação e sexualidade conjugal; repercussões da doença; o cuidado e a abordagem profissional; atitudes, crenças e imaginário social de sexualidade e cuidado; relação familiar e ressignificação de sexualidade. Considerações finais: compreendeu-se a construção de vida familiar e conjugal; os aspectos de formação e desenvolvimento da sexualidade; as especificidades que envolvem viver e cuidar do outro, com sucessivos acontecimentos e mudanças influenciados pela velhice, por processo demencial, crenças e imaginário social.

Descritores: Demência; Teoria de Enfermagem; Sexualidade; Cuidados de Enfermagem; Idoso.

\section{RESUMEN}

Objetivo: Comprender las transiciones experimentadas, sus condiciones y patrones de respuesta esperados em el cambio de la sexualidad de los cónyuges cuidadores de ancianos em proceso de demencia. Método: investigación cualitativa, llevada a cabo em la clínica neurogeriatrica entre mayo de 2014 y mayo de 2015. Se aplicó una entrevista individual e intensiva a 12 cónyuges cuidadores de los ancianos. Se hizo análisis de contenido temático com el modelo teórico de la Teoría de las Transiciones. Resultados: siete categorias surgieron, que implican relación conyugal y la sexualidad; repercusiones de la enfermedad; atención y enfoque profesional; las actitudes, creencias y imágenes sociales de la sexualidad y el cuidado; relaciones familiares y 
resignificación de la sexualidad. Consideraciones finales: se comprendió la construcción de la vida conyugal y familiar; aspectos de la formación y eldesarrollo de la sexualidad; las especificidades de viver y dar atención para elotro, com los sucesivos eventos y cambios influenciados por la vejez, el proceso de la demencia, las creencias y la imaginación social.

Descriptores: Demencia; Teoría de Enfermería; Sexualidad; Atención de Enfermería; Anciano.

\section{INTRODUCTION}

According to The World Alzheimer Report 2015, it is estimated that there are 46.8 million people with dementia in the world. This number will almost double in 20 years, and the disease could reach 74.7 million individuals in 2030, and 131.5 million in $2050^{(1)}$.

Dementia generates progressive cognitive losses, physical and mental incapacity, with possible difficulties for maintenance of conjugal sexuality. Without viable alternatives, or when family skills and resources are insufficient to handle the necessary adaptations, a strong tendency towards individual and family disorganization is evident, with negative consequences for the couple's care, well-being, and sexuality.

In this context, the nurse's attention to the sexuality of the elderly spouse-caregiver is relevant, especially regarding the exchange of information and support for the diseases that may interfere with the development of their own sexuality, or in the sexual contact with the caregiver ${ }^{(2)}$. The real demands must be identified, using systematic articulation, to describe phenomena, the relation between them, to foresee influences and to prescribe appropriate care, based on a theoretical nursing reference $^{(3)}$. Nursing theories provide an integral understanding of the principles of this discipline, aiming at its incorporation in the practice of nursing ${ }^{(4)}$.

Thus, this study was based on the Theory of Transitions, a theoretical framework that describes the nature of transitions (types, patterns and properties), facilitating/inhibiting conditions (personal, meaning, cultural attitudes and beliefs, socioeconomic status, knowledge, connection to community and societal influences) and response patterns (process indicators and properties), by the possibility of elucidating facts occurring in the social context and in groups of people,understanding their meanings. The sexual changes experienced by the spouses-caregivers include feelings that must be understood in order to better conduct nursing therapies ${ }^{(3)}$.

\section{OBJECTIVE}

To understand the nature of their own transitions, conditions and patterns of response to changes in the sexuality of the elderly spouse-caregiver, based on the theoretical model of Afaf Meleis.

\section{METHODS}

\section{Ethical aspects}

Participants were guided on the purpose of the study. The Terms of Free and Informed Consent form was read and signed before the data collection began. The anonymity of the participants was ensured by the identification of the interviews by the letter $\mathrm{E}$ followed by an arabic number corresponding to the sequential order in which they were performed (E1 to E12). The study was approved by the Ethics and Research Committee of the University of the State of Rio de Janeiro.

\section{Type of study}

This was an exploratory study, with a qualitative approach, aiming to identify the nature of the transitions, favorable/ inhibiting conditions and the expected response patterns to changes experienced in the sexuality of the couple, because they are aspects that drive nursing therapeutics in the context of care for the elderly during the process of dementia.

\section{Study Scenario and Data Source}

The study was conducted at the Neurogeriatrics Outpatient Clinic of the University of the State of Rio de Janeiro (UERJ), a unit specialized in the care of the elderly with dependence and/or greater risk of frailty, using specific projects in neurogeriatry, urogeriatry and cognitive optimization of elderly, involving the family.

The group of participants was comprised of 12 spousescaregivers, the number being defined after theoretical saturation was reached. For inclusion in the study, two criteria were established: being the spouse of an elderly individual experiencing a dementia process, with the steps defined by cognitive evaluation scales: Global Deterioration Scale, step 3 to 5 (mild to moderate), Mini Mental Test and Clinical Dementia Rating, and spouse-caregiver/companion of the elderly during the dementia process at home andin the outpatient clinic.

\section{Collection and data organization}

The data were collected from May/2014 to May/2015, by means of an intensive individual interview, a technique applicable to studies of a qualitative nature, with a detailed examination of experiences, valid for interpretive research ${ }^{(5)}$. The interviews were private, and were conducted at the clinic at times that were previouslyscheduled, and were guided by the following question: How does the elderly spouse-caregiver in a dementia process experience the transitionally of sexuality in the conjugal relationship?

\section{Data analysis}

For the analytical procedure, thematic content analysis ${ }^{(6)}$ was used, by means of detailed transcripts of the interviews recorded in digital media, and exploratory pre-analysis of the material, by readings and organization of the findings. Finally, treatment and interpretation of the data was performed based on the theoretical model of Transition Theory ${ }^{(3)}$, which 
allowed the development of seven categories and 16 subcategories, which are presented in Table 1 of the results section.

\section{RESULTS}

Participants were between 63 and 88 years of age; seven men and five women; level of education varied from four to
11 years of study; time as spouse-caregiver ranged from one to ten years; nine were alone in the caregiving role, and three had family member support and/or a formal caregiver.

After analyzing the categories/subcategories, elements of the theoretical model of Transition Theory were identified, which comprised the nursing therapeutic care model before the transition of the sexuality of the spouse-caregiver, according to Chart 1:

Chart 1 - Categories and subcategories according to Transition Theory, Rio de Janeiro, Brazil, 2015

\begin{tabular}{|c|c|c|}
\hline Categories & Subcategories & Nursing therapeutic care \\
\hline $\begin{array}{l}\text { 1. Experiencing } \\
\text { transitions in the } \\
\text { marital relationship } \\
\text { and repercussions } \\
\text { in the course of the } \\
\text { dementia process of } \\
\text { the elderly. }\end{array}$ & $\begin{array}{l}\text { 1.Describing the development of the } \\
\text { conjugal relationship. } \\
\text { 2. Looking at married life and changes } \\
\text { during the dementia process of the } \\
\text { elderly. } \\
\text { 3. Facing the dementia process of the } \\
\text { elderly and the repercussions on } \\
\text { personal and marital life. } \\
\text { 4. Living with changes in the health of } \\
\text { the spouse-caregiver resulting from the } \\
\text { dementia process of the elderly }\end{array}$ & $\begin{array}{l}\text { Nature of transitions: } \\
\text { Type: Situational. } \\
\text { - Pattern: Sequential. } \\
\text { - Property: Change and difference } \\
\text { Conditions: Meanings. } \\
\text { Response Patterns: Identifying changes and interferences in the } \\
\text { marital relationship }\end{array}$ \\
\hline $\begin{array}{l}\text { 2. Understanding } \\
\text { the dimensions of } \\
\text { conjugal sexuality } \\
\text { and the changes } \\
\text { imposed by the } \\
\text { dementia process of } \\
\text { the elderly. }\end{array}$ & $\begin{array}{l}\text { 5. Experiencing the dimensions of } \\
\text { conjugal sexuality before and after the } \\
\text { dementia process of the elderly. } \\
\text { 6. Dealing with changes in sexuality in the } \\
\text { course of the dementia process of the } \\
\text { elderly. }\end{array}$ & $\begin{array}{l}\text { Nature of transitions: } \\
\text { Type: Health / disease. } \\
\text { - Pattern: Sequential. } \\
\text { - Property: Change and difference. } \\
\text { Conditions: Meaning. } \\
\text { Response Patterns: Having autonomy for making own decisions } \\
\text { care. }\end{array}$ \\
\hline $\begin{array}{l}\text { 3.Experiencing care } \\
\text { for the elderly in the } \\
\text { dementia process. }\end{array}$ & $\begin{array}{l}\text { 7. Getting involved in the care of the } \\
\text { elderly during the dementia process. } \\
\text { 8. Giving meaning to the care and } \\
\text { repercussions in the context of the } \\
\text { dementia process of the elderly. }\end{array}$ & $\begin{array}{l}\text { Nature of transitions: } \\
\text {-Type: Situational. } \\
\text { - Pattern: Multiple. } \\
\text { - Property: Involvement. } \\
\text { Conditions: Level of preparation; Knowledge / skill. } \\
\text { Response patterns: Ability to self-assess the marital relationship. }\end{array}$ \\
\hline $\begin{array}{l}\text { 4. Understanding } \\
\text { the importance of } \\
\text { the professional } \\
\text { approach on } \\
\text { sexuality and } \\
\text { care in the } \\
\text { dementiaprocessof } \\
\text { the elderly. }\end{array}$ & $\begin{array}{l}\text { 9. Identifying the need for a professional } \\
\text { approach about sexuality for the } \\
\text { spouse-caregiver and/or the elderly in a } \\
\text { dementia process. } \\
\text { 10. Highlighting the importance of the } \\
\text { support provided by Geriatrics and } \\
\text { Gerontology. }\end{array}$ & $\begin{array}{l}\text { Nature of transitions:: } \\
\text { - Type: organizational. } \\
\text { - Pattern: Sequential. } \\
\text { - Property: Awareness. } \\
\text { Critical points and events } \\
\text { Conditions: Level of preparation and knowledge/ability. } \\
\text { Response Patterns: Ability to identify and address issues of } \\
\text { sexuality and care. }\end{array}$ \\
\hline $\begin{array}{l}\text { 5. Expressing the } \\
\text { attitudes, beliefs } \\
\text { and social imagery } \\
\text { that permeate } \\
\text { sexuality and care. }\end{array}$ & $\begin{array}{l}\text { 11. Sharing attitudes and beliefs about } \\
\text { individual and marital sexuality. } \\
\text { 12. Revealing the social imagery of } \\
\text { sexuality and care. }\end{array}$ & $\begin{array}{l}\text { Nature of transitions:: } \\
\text { - Type: situational. } \\
\text { - Pattern: Related. } \\
\text { - Property: Critical points and events. } \\
\text { Conditions: Attitudes and beliefs; Meanings } \\
\text { (the imaginary). } \\
\text { Response Patterns: Ability to critically assess the social role of the } \\
\text { spouse-caregiver. }\end{array}$ \\
\hline $\begin{array}{l}\text { 6. Describing the } \\
\text { connections of the } \\
\text { family relationship } \\
\text { and the dementia } \\
\text { process of the } \\
\text { elderly. }\end{array}$ & $\begin{array}{l}\text { 13. Perceiving relational and interactional } \\
\text { aspects between family and elderly in } \\
\text { the process of dementia. } \\
\text { 14. Recognizing the lack of } \\
\text { communication in the family } \\
\text { relationship. }\end{array}$ & $\begin{array}{l}\text { Nature of transitions:: } \\
\text { - Type: situational. } \\
\text { - Pattern: related. } \\
\text { - Property: connection. } \\
\text { Conditions: Meanings and level of preparation and knowledge/ } \\
\text { skills. } \\
\text { Response Patterns: Understanding the family relationship } \\
\text { regarding the dementia process. }\end{array}$ \\
\hline $\begin{array}{l}\text { 7. Redefining personal } \\
\text { and conjugal } \\
\text { sexuality }\end{array}$ & $\begin{array}{l}\text { 15. Developing strategies to cope with } \\
\text { the dementia process of the elderly, } \\
\text { aimed at the personal and conjugal } \\
\text { experience of sexuality. } \\
\text { 16. Experiencing the transposition of } \\
\text { sexuality by means of caring for the } \\
\text { elderly in a dementia process. }\end{array}$ & $\begin{array}{l}\text { Nature of transitions: } \\
\text { - Type: Developmental, sequential. } \\
\text { - Pattern: Related. } \\
\text { - Property: Awareness, involvement, transition time. } \\
\text { Conditions: meaning, preparation and knowledge/ skills. } \\
\text { Response Patterns: Seeking the satisfaction of needs related to } \\
\text { conjugal sexuality, in a re-defined manner. }\end{array}$ \\
\hline
\end{tabular}


Experiencing transitions in the marital relationship and repercussions in the course of the dementia process of the elderly

This category describes the marital relationship, with predominance of a narrative of coexistence, developed with the affectivity, companionship, dialogue and care for the other; in the changes imposed by the dementia process of the elderly, in particular the altered behavioral manifestations, loss of the life routine, and discontinuity of the couple's relationship; in the confrontation and repercussions of an exhausting routine and physical and mental overload, with decline of self-care, financial loss, reduced privacy, little social interaction and conformism; on the physical and psycho-emotional effects of the spouse-caregiver.

In a way, his illness has interfered with our lives. The person I met was changing, transforming. Life today is tumultuous and I feel the interferences [...]. (E7)

We lived for 58 years, a good life together ... I still care for her today. (E11)

Understanding the dimensions of conjugal sexuality and the changes imposed by the dementia process of the elderly

The dimensions of sexuality in the marital relationship emerged with meanings of interaction between love and sex, capable of generating vitality, even with differentiations over time. Changes in the conjugal sexuality due to the dementia process of the elderly arise from difficulties in maintaining hygiene, altered self-esteem and hypersexuality.

He does not give me rest, now our life is like that, he always wants sex. I lost what I had of attractiveness; today I am a finished woman and my self-esteem in low. (E1)

I think sexuality gives vigor to life, leads the relationship forward. (E7)

[...] Even when we had sex, life was like that, he only cared about the sex [...], with age he became unsure about some things in sex. (E8)

Experiencing care for the elderly in a process of dementia

The reports showed an understanding of the meaning of care based on the subjectivity of one's own life with the elderly in the process of dementia, despite a strong focus on maintaining daily life activities, safety and availability due to a sense of duty/mission. The repercussions for the spouse-caregiver were expressed by ambiguous feelings: happiness/sadness and bad mood/sadness.

The answer is physician, medicine, and patience. What I do is give the pills and go to the doctor. No way I can leave him alone, if I do, he falls, he can take a knife and get hurt... (E7)

Caring is to take responsibility for someone who needs it, is to treat him well. The daily routine of the disease, taking care of him, I do not give up; I do not give up on my duty.(E10)

Many things go through my head, a daily uneasiness, but I had to stand firm, taking care of her. While I was caring, I thought abouther illness, I was sad, depressed. (E12)
Understanding the importance of the professional approach to sexuality and care in the elderly process of dementia

The need for a professional approach about conjugal sexuality and caring for the elderly in a dementia process was identified, even regarding the appreciation and recognition of the specialized service by the spouse-caregiver. It was noticed that actions focused on orientation about the disease and its progress, difficulty of approaching the issue when the dementia process is in progress or when the demand is of the spouse-caregiver. Some statements indicated differentiations in approach from the perspective of men and women.

[...] I looked for the specialized service in Geriatrics and Gerontology, and there the Alzheimer's was diagnosed and the treatment started in 2011, it was very good! (E6)

I think it's an important issue to be addressed. It may be interfering with other health issues, physical or mental, but I feel there is some embarrassment [...]. (E9)

Expressing the attitudes, beliefs and social imagery that permeate sexuality and care

Attitudes and beliefs about sexuality of the spouse-caregiver have turned to the family history, previous sexual experiences and culture. Concerning conjugal sexuality, aspects of self-care and vanity were highlighted. In the social imagery of care, there is self-perception, belief and the social role; for the imagery of sexuality, the permanence of sexual desire, the medications, and social conventions.

He never had the vanity to be clean, and smelly, that bothers me! (E1)

He took care of it, but now it is me, is a reversal of roles [...]. I want to have my sexuality, but what would people say about me? (E2)

My sexual development was chastity until my marriage [...]. (E5)

Describing connections of the family relationship and the dementia process of the elderly

The statement revealed that family relationships were permeated by conflicts, incapacity or restricted availability of family cares for the elderly, and barely fulfilling the obligations as parents. As for sexuality, dialogue and sex education were considered flawed.

I'm cool, because I did my part; I met all the obligations of being a mother. (E2)

The daughter works, the granddaughter studies, I have to do things, take care of him. (E3)

My mother never talked to me about sex! (E4)

Redefining personal and conjugal sexuality

Supporting chronic care for the elderly in a dementia process, the spouse-caregiver seeks strategies to overcome 
difficulties in different ways: spirituality, preservation of differentiated sexuality, support and donation, improvement of self-knowledge and self-image.

What supports me is the Catholic faith. The disease turned us into friends. Today I feel the same affection, love, even with the change that the disease has been making. I understand that things change and we need to change our focus as well. (E5)

I consider him as my husband. I like him very much, I have affection, I give him a kiss on the forehead, he sleeps and I hug him. For me it's a manner of living my sexuality, taking care. As for me, even in the rush, I try to take care of myself, preserving my self-image. (E8)

\section{DISCUSSION}

The results of the research were presented in a consistent way with the occurrence of the facts and consistent with the assumptions of the applied theoretical framework. Thus, the discussion considers the nature of the transitions according to the succession of facts, the conditions in which they occurred, and the expected response patterns in regard to therapeutic nursing care.

Transitions generate changes, but not always a transitional process, which depends on the person involved ${ }^{(3)}$. This experience and the repercussions imposed by the disease depend on the meanings attributed by individuals, based on their experiences and their perception of their lived reality. Therefore, it is expected that the transitional response patterns, monitored by the indicators that translate the level of knowledge and performance necessary for new situations, will lead the caregiver to identify what changes and repercussions happen, as, if they are healthy, they result in mastery; otherwise, in role performance $\operatorname{deficit}^{(7)}$.

During this process, the factors involved in the common life mechanism for valuing the relationship, for example, dialogue, for the majority of participants, which were established and preserved throughout the marriage, become important. This is an important aspect of conjugality, as it is an effective instrument for solving conflicts in adjustment processes, with negotiations that legitimize affectivity and an intimate relationship ${ }^{(8)}$. The characteristics of the personality of the spouses can interfere positively or negatively, and are related to the couple's specificities. Thus, it is postulated that one of the best predictors of long-term marital success is the manner of dealing with conflicts, differences and difficulties ${ }^{(9)}$.

The changes experienced with dementia affect the marriage, by changes in routine perceived by preexisting misalignments in the relationship; emergence of behaviors that generate burden in the caregiver; and the imminent need for readaptation to new, and unusual demands. Caregivers are coping with multiple and challenging tasks, such as accepting a diagnosis, managing conflicts, and rescheduling the future ${ }^{(10)}$. The advancement of the disease and the worsening of the functional performance of the elderly generate impacts on the health of the caregiver, and one of the most important problems caused by dementia is the burden it imposes on several aspects of life ${ }^{(11-12)}$.
The chronic health problems of caregivers make them sick, and lead to their consuming more medicines and alcohol. As the behavior of the elderly changes, the greater the worsening tendency of this illness becomes ${ }^{(13-14)}$. In fact, the caregiver demands a complete availability of actions, with a rupture and redefinition of the way of life, often characterized by the fragile limit between his life and that of the other, with less time for leisure, social life, family and affective behaviors. In this process, they experience economic difficulties, family conflicts and labor problems ${ }^{(11)}$.

Transitions are the result of various changes ${ }^{(7)}$ and understanding them requires understanding the meaning of the events that underlie the experiences. Therefore, autonomy for making their own decisions regarding modified conjugal sexuality is expected as a pattern of response of the spouses-caregivers.

There was an association between sexuality and affection, which was identified by loving, friendship, companionship and affection, feelings that generate satisfaction, maintaining intimacy and interdependence. Conjugality in old age is linked to intimacy, companionship and expression of feelings, in a climate of security, affection and reciprocity, even with differences ${ }^{(15)}$.

In this sense, the recognition of changes in sexuality with age was noticed, but still with possible sexual satisfaction through positive harmony of the couple, that ends up creating more viable conditions of adaptation. Thus, it is possible to get closer to the elderly, based on love and companionship, and this new experience of sexuality can generate other adaptations and reinventions ${ }^{(16)}$. However, the misalignment in conjugal affective relationships, by means of conflicts and resentments, can drive one away and cause sexual coldness, far beyond the disease.

Even prior to dementia, the elderly and spouses lived with chronic diseases and interferences in sexuality. A systematic review demonstrated evidence of the impact of biological variables on sexual function, due to deleterious effects that may be irreversible. The couple'ssexual behaviorsare different in rhythm and frequency, searching for physical and sexual contact, reiterating the idea that elder men seem to have more interest, activity and quality of sexual life than women at this stage of life, even with decreased activity, quality and frequency of sexual response due to age and health changes ${ }^{(17)}$.

Hypersexuality, progressive sexual absence, altered self-management, and sex substitution by affection has been reported in the development of dementia. Hypersexuality is characterized by insatiable sexual desire or sexual disinhibition, characteristic of changes in dementia courses and causing conflicts and relationships distress ${ }^{(18)}$. The removal of the condition of conjugality occurs by the dementia itself, justified by physical and psychological aspects of overload and loss of intimacy, with the spouses-caregivers the most sexually affected ${ }^{(11)}$.

The condition of caring for the other depends on the level of preparation and knowledge, as the process of reconstructing one's role requires a break with what is normal and expected in the daily life, so that the events for making new decisions and skills are evaluated. The earlier the preparation for this new function, the better the transition, by means of prior knowledge, use of strategies and development of meanings. 
Therefore, the expected transition response pattern is the ability of the caregiver-spouses to self-assess the care provided.

The transition began with the meaning of care for spousescaregivers, linked with love, caring, tolerance, dedication and respect for limitations between caregivers and the cared-for individuals. Elderly relatives of the Home Care Program of the University Hospital of the University of São Paulo (USP), when questioned about feelings experienced in care delivery, expressed zeal, affection, gratitude and the desire to remain with the family member for as long as possible, strengthening the relationship and reducing the difficulties of caring ${ }^{(19)}$. The most common care activities for the spouse-caregiver are those for health control and organization of home care. They are confronted with challenging tasks, especially those related to the administration of medications ${ }^{(20)}$.

Caring, according to spouses-caregivers, requires availability that is often considered a duty, because of the needs of the elderly patient spent by pleasure and dedication, despite the burden. Love is the foundation; it is an obligation to fight and remain firm, for coexistence, regardless of the circumstances, and by appreciation of caring for the companion ${ }^{(20)}$.

In the study, the number of male spouses-caregivers was slightly higher, although, in general, the most common configuration of caring activities is by females, by the social vision developed and expected in the domestic sphere, transferred between generations ${ }^{(21)}$. The social responsibility of care, historically attributed to women, is no longer exclusively female, since men are already affectively involved in the care of family members, children, sick individuals, and himself ${ }^{(22)}$.

The awareness of the professional approach to sexuality and dementia care, according to the nature of transitions, is classified as organizational, by association with changes in the social, political and/or economic spheres, as well as changes in the structure and dynamics of organizations ${ }^{(3)}$. The sequential condition of situations is maintained as a standard, both for those who live the transition and those who support its mastery. Thus, the property required by the professionals advances through the awareness of facts and needs arising in relation to sexual demands, care and critical points/events evidenced before and during the transitions. Nevertheless, events/critical points can interfere with the evolution of the transition, when they influence the rhythm, one's own awareness and involvement in the care. It is up to those involved to identify and relate them to difficulties or successes in the process, for the stabilization of life, focusing on self-care, new skills and readapted lifestyle ${ }^{(7)}$.

Effective awareness of the professional approach to sexuality and care depends on the level of preparation and knowledge/skill, as the changes in everyday practice require understanding for decision-making and skills in the new life circumstance, with a focus on competencies. Therefore, the expected response pattern is to be able, as a health professional, to identify and address issues of sexuality and care with this clientele.

The elderly with dementia depend on caregivers, often informal caregivers, who are often not prepared to provide specific care ${ }^{(23)}$, which requires support. As for sexuality, there is a deficient approach in individual or team care, justified by reduced time, prioritization of general health issues or of dementia, and a greater number of visits of women, who require less information about sexuality.

Sexual practices among those who are aging is also little discussed. Health professionals commonly ignore the issue, by emphasizing other subjects, underestimating strategies of approach, difficulty in establishing communication links, embarrassment, and lack of receptivity of the elderly ${ }^{(24)}$. The lack of professional vision about sexuality of the elderly, marital life and chronic disease causes the fragmentation of care actions and reflects the fragility in the health care for this population, as well as obstacles to strengthening of comprehensive practices in services ${ }^{(25)}$.

The nature of transitions in terms of expressions of attitudes, beliefs and social imagery of sexuality and care is situational, because of dementia itself and because it is associated with the definition or redefinition of social roles in the face of sexuality and care $^{(3)}$.

Critical points and events may represent causes or consequences of attitudes, influences of beliefs and social imagery. Attitudes express a tendency to respond or act in a certain way toward what is around, moving away or approaching the fact. Thus, the identification of critical points and events will be important for nurses to plan and operationalize therapies in order to support individuals in transition ${ }^{(7)}$. As a response pattern, it is expected that the spouses-caregivers will be able to critically evaluate the social role.

Sexuality, at an advanced stage of life, needs to be viewed in a manner that does not restrict it to biological aspects. It is necessary to pay attention to the needs imposed by older age and by searching for less predetermined care possibilities ${ }^{(26)}$. The conception of sexuality is also related to the time of birth of the elderly, a predominance of rigid moral and religious ideals, curtailing sexual feelings and desires, and the repression of dialogue and sexual life.

In the context of a conjugal life, the importance of the relationship with the partner, the concern for his/her well-being and self-care, and the attempt to maintain his/her self-esteem, in order to manage the elderly patient, were highlighted. With the difficulties of maintaining sexual activity, it is common for the elderly to make sexual adaptations, since the body no longer responds to desire, with emphasis on respect, friendship, love and kindness ${ }^{(15,27)}$.

In the contextualization of the social imagery, the sexual desire of the spouse-caregiver remains, although reprimanded by social precepts in relation to old age, sexuality and chronic illness. Sometimes older women surrender to the social appeal for a more discreet life that does not demonstrate their need for an active, even differentiated sexual life. The myth of asexual old age is updated daily, which reinforces the image that the elderly, when expressing their sexuality, present as deviants ${ }^{(25)}$. Sex is practiced in the context of the family social institution and marriage, having almost always achieved the procreative function and, therefore, the gradual decrease or even the abandonment of sexual practice seems to gain a more natural acceptancein this group ${ }^{(28)}$. 
The social imagery of care points to: the infantilization of the elderly in a dementia process on the part of the spouse-caregiver, due to the fragility and dependence; role reversal between men and women; perception of the physical aging process as a caregiver; view of care as a retribution. In dementia, playing the role of family caregiver can generate a burden and interfere with one's own aging. Thus, the perception of the elderly about their body image also influences their behavior and self-esteem ${ }^{(29)}$.

The family is the pillar of support, the first social unit of integration and an institution that contributes to development and socialization. Care is perceived as one of the most basic functions of family life, constituting a dynamic and complex process. The presence of the spouse among family caregivers and an increase in the care burden of their partners is emphasized $^{(30)}$, with risks for the organization and maintenance of chronic care, especially for their longevity. In the perspective of the redefinition of personal and conjugal sexuality, the nature of the transitions encompassed, by means of strategies and care, developmental and situational characteristics, by association with chronic disease and by virtue of the need to define or redefine the repertoire of social roles as a person and family member ${ }^{(3)}$.

When complex transitions were present, the pattern of occurrence was related to diverse demands and even understanding of a redefinition. Propriety included awareness, which involves perception, knowledge, and recognition of the transition experience; the involvement and the degree to which one is involved with it; and the time to adapt to the new way of being. The pattern stems from the rupture between the known and living with the changes of the transition, which requires adjustments to reach equilibrium ${ }^{(3)}$.

In the condition, the meanings and the level of preparation were integrated, as well as the knowledge/abilities acquired until then. Based on the meanings developed, experiences are lived; expressions of reality and actions are taken, which characterize the transitional process. The greater the acquisition of knowledge and new skills with the current situation, the better the restructuring of the broad identity of married life. Therefore, the pattern of response is to seek the satisfaction of the needs related to conjugal sexuality.

The spouse-caregiver practices strategies to live the couple's and his/her personal sexuality in a new manner. The transposition of the sexual occurs through care, so that the vision of pleasure overcomes the genital, by love that is developed and supported. Coexistence in the context of the experience between old age and sexuality is permeated by affection, romantic love and companionship, capable of satisfying the individual and the couple, in such a way that the limitations of life, health and the context of the world end up little valued. Therefore, based on love, friendship and faith, they may experience new possibilities of adjustments and reinventions of sexuality ${ }^{(15)}$.

\section{Study limitations}

It is highlighted, as a limitation of the study, the difficulty in discussing the findings in light of other studies on the subject, given the scarcity of publications in the research area.

\section{Contributions to health and nursing}

The study contributes to health and to the geriatric and gerontological nursing area, supporting the knowledge of topics and theoretical references that have been little explored; with specialized services, caring for the elderly based on innovative ways of caring; and in the nursing consultation, by means of investigation of aspects related to sexuality and the development of strategies to support spouses-caregivers, based on the assumptions of Meleis' Theory of Transition. Investigating other realities, from the perspective of sexuality, dementia and the spouse-caregiver, can support new ways of offering gerontological care.

\section{FINAL CONSIDERATIONS}

The articulation of categories/subcategories points to the understanding of the nature of the transitions experienced, and the conditions and the patterns of expected responses to changes experienced in sexuality by spouses-caregivers of elderly people in the process of dementia. It reveals conditions that underlie the conjugal relationship to sexuality, before and after the context of the disease. These changes have given rise to different dimensions, both for adapting and reorganizing life, and for caring for oneself and the other, based on beliefs, social imagery, family support, and awareness on the importance of addressing sexuality, professionally, in the field of health.

Therapeutic nursing care should be have theoretical bases, in order to ensure that all possibilities are dimensioned and conducted for the connection, interaction, involvement, trust and coping of transitions by the individuals who experience them, instrumentalizing the work of nursing.

\section{REFERENCES}

1. Prince M, Wimo A, Guerchet M, Gemma-Claire A, Wu Y-T, Prina M. World Alzheimer Report 2015: The Global Impact of Dementia: an analysis of prevalence, incidence, cost and trends. Alzheimer's Dis Int [Internet]. 2015 [cited 2016 May 15];84p. Available from: https:// www.alz.co.uk/research/world-report-2015

2. Santos AS, Arduini JB, Silva LC, Fonseca AS. Understanding of the elderly and their relatives regarding sexuality and HIV/AIDS: a descriptive study. Online Braz J Nurs [Internet]. 2014 Jun [cited May 25 2016];13(2):175-85. Available from: http://www. objnursing.uff. br/index.php/nursing/article/view/4326

3. Meleis AI. Theoretical nursing: development and progress. 5th ed. Philadelphia, USA: J. B. Lippincott \& Co; 2012.

4. Ramalho Neto JM, Marques DKA, Fernandes MGM, Nóbrega MML. Meleis' Nursing Theories Evaluation: integrative review. Rev 
Bras Enferm [Internet]. 2016[cited 2016 May 15];69(1):174-81. Available from: http://www.scielo.br/pdf/reben/v69n1/en_0034-7167reben-69-01-0174.pdf

5. Charmaz K. Constructing grounded theory: a practical guide through qualitative analysis. New York, USA: Sage Publications; 2014.

6. Bardin L. Análise de conteúdo. 6ª ed. Reto LA, Pinheiro A, (Trad). São Paulo: Livraria Martins Fontes; 2011.

7. Meleis AI, Sawyer LM, Im E-O, Hilfinger Messias DK, Schumacher K. Experiencing Transitions: An Emerging Middle-Range Theory. Adv Nurs Sci [Internet]. 2000 [cited 2016 May 15];23(1):12-28. Available from: http://journals.Iww.com/advancesinnursingscience/ Fulltext/2000/09000/ExperiencingTransitionsAnEmergingMiddleRange.6.aspx

8. Bueno RK, Souza SA de, Monteiro MA, Teixeira RHM. Process of Differentiation of Couples from Their Families of Origin. Psico [Internet]. 2013 [cited 2016 May 15];44(1):16-25. Available from: http://revistaseletronicas.pucrs.br/ojs/index.php/revistapsico/article/ view/9420/8843

9. Bolze SD, Crepaldi MA, Schmidt B, Vieira M. Marital Relationship and Tactics of Conflict Resolution between Couples. Actual Psicol [Internet]. 2013 [cited 2016 May 25];27(114):71-85. Available from: http://pepsic.bvsalud.org/scielo.php?script=sci_arttext\&pid $=$ S0258-64442013000100006

10. Silva CF da, Passos VMA, Barreto SM. Frequency and impact of the burden on family caregivers of elderly with dementia. Rev Bras Geriatr Gerontol [Internet]. 2012 [cited 2016 May 27];15(4):707-31. Available from: http://www.scielo.br/pdf/rbgg/v15n4/11.pdf

11. Bauab JP, Emmel MLG. Changes in the daily lives of caregivers of elderly in process of dementia. Rev Bras Geriatr Gerontol [Internet]. 2014 [cited 2016 May 15];17(2):339-52. Available from: http://www.scielo.br/pdf/rbgg/v17n2/1809-9823-rbgg-17-02-00339.pdf

12. Talmelli LFS, Vale FAC, Gratão ACM, Kusumota L, Rodrigues RAP. Alzheimer's disease: functional decline and stage of dementia. Acta Paul Enferm [Internet]. 2013 [cited 2016 May 15];26(3):219-25. Available from: http://www.scielo.br/pdf/ape/v26n3/en_03.pdf

13. Cheng S-TT, Lau RWL, Mak EPM, Ng NSS, Lam LCW, Fung HH, et al. A benefit-finding intervention for family caregivers of persons with Alzheimer disease: study protocol of a randomized controlled trial. Trials [Internet]. 2012 [cited 2016 May 15];13(1):1-7. Available from: http://www.ncbi.nlm.nih.gov/pmc/articles/PMC3413525/

14. Zverová M. Frequency of some psychosomatic symptoms in informal caregivers of Alzheimer's disease individuals. Prague's experience. Act Nerv Super Rediviva [Internet]. 2012 [cited 2016 May 15];54(2):77-132. Available from: http://www.rediviva.sav.sk/54i2/77.pdf

15. Moraes KM, Vasconcelos DP, Silva ASR da, Silva RCC da, Santiago LMM, Freitas CASL. The beauty of companionship and sexuality for couples in the best age: caring for elderly couple. Rev Bras Geriatr Gerontol [Internet]. 2011 [cited 2016 May 15];14(4):787-98. Available from: http://www.scielo.br/pdf/rbgg/v14n4/a18v14n4.pdf

16. Catapan NR, Brito RS, Cavalcanti PP, Pereira DL, Torres N. Understanding senescence from the perspective of female sexuality. Ciênc Praxis. 2015;7(14):19-24.

17. Fleury HJ, Abdo CHN. Aging, chronic diseases and sexual function. Diagn Tratamento [Internet]. 2012 [cited 2016 May 15];17(4):201-5. Available from: http://files.bvs.br/upload/S/1413-9979/2012/v17n4/a3340.pdf

18. Fonseca AM, Soares E. The care taker's discourse about taking care of the elderly with alzheimer's disease. Rev Rene [Internet]. 2008 [cited 2016 May 15];9(3):99-107. Available from: http://www.revistarene.ufc.br/revista/index.php/revista/article/view/607/pdf

19. Fratezi FR, Gutierrez BAO. [Family caregiver of elderly patients in palliative care: the process of dying at home]. Ciênc Saúde Colet [Internet]. 2011 [cited 2016 May 15];16(7):3241-8. Available from: http://www.scielo.br/pdf/csc/v16n7/23.pdf Portuguese.

20. Linhares BN, Vianna LG. Fardo do cuidador familiar de idoso com demência de Alzheimer: consequências em sua vida conjugal. Rev Med Saúde Brasilia [Internet]. 2015 [cited 2016 May 15];4(2):157-65. Available from: http://portalrevistas.ucb.br/index.php/rmsbr/article/ viewFile/5894/3959

21. Colomé ICS, Marqui ABT, Jahn AC, Resta DG, Carli R, Winck MT et al. Taking care of institutionalized elders: characteristics and difficulties of the caregivers. Rev Eletr Enf [Internet]. 2011 [cited 2016 May 15];13(2):306-12. Available from: https://www.fen.ufg.br/revista/v13/n2/ v13n2a17.htm

22. Flores GC. Borges ZN, Budó MLD, Silva FM da. The gift of caregiving: qualitative study about the intergenerational care given to the elderly. Cienc Cuid Saúde [Internet]. 2011 [cited 2016 May15];10(3):533-40. Available from: http://periodicos.uem.br/ojs/index.php/ CiencCuidSaude/article/view/11683/pdf

23. Seima MD, Lenardt MH. Family caregiver burden caring for the elderly with Alzheimer's disease. Textos Contextos [Internet]. 2011 [cited 2016 May 15];10(2):388-98. Available from: http://revistaseletronicas.pucrs.br/ojs/index.php/fass/article/view/9901/7341

24. Bernardo R, Cortina I. Sexualidade na terceira idade. Rev Enferm UNISA [Internet]. 2012 [cited 2016 May 15];13(1):74-8. Available form: http://www.unisa.br/graduacao/biologicas/enfer/revista/arquivos/2012-1-13.pdf

25. Laroque MF, Affeldt AB, Cardoso DH, Souza GL de, Santana MG, Lange C. [Sexuality of the elderly: behavior for the prevention of STD/ AIDS]. Rev Gaúcha Enferm [Internet]. 2011 [cited 2016 May 15];32(4):774-80. Available from: http://www.scielo.br/pdf/rgenf/v32n4/ v32n4a19.pdf Portuguese.

26. Vieira KFL, Miranda RS, Coutinho MPL. Sexuality in old age: a social representations study. Psicologia e Saber Social. [Internet]. 2012 [cited 2016 May 15];1(1):120-8. Available from: http://www.e-publicacoes.uerj.br/index.php/psi-sabersocial/article/view/3250/2257

27. Alencar DL de, Marques APO, Leal MCC, Vieira JCM. [Factors that influence the sexuality of the elderly: an integrative review]. Ciênc 
Saúde Colet [Internet]. 2014[cited 2016 May 15];19(8):3533-42. Available from: http://www.scielo.br/pdf/csc/v19n8/1413-8123csc-19-08-03533.pdf Portuguese.

28. Maravilha LMM, Santos MFS, Gouveia RC de, Almeida AMO. As representações sociais de envelhecimento masculino e as diferentes vivências da sexualidade. RBCEH [Internet]. 2013 [cited 2016 May 15];10(1):79-91. Available from: http://www.upf.br/seer/index.php/ rbceh/article/view/1905/pdf

29. Bastos CC, Closs VE, Pereira AMVB, Batista C, Idalêncio FA, De Carli GA. [Importance given to sex by the elderly in the city of Porto Alegre and association between self-health perception and the feeling of happiness]. Rev Bras Geriatr Gerontol [Internet]. 2012 [cited 2016 May 27];15(1):87-95. Available from: http://www.scielo.br/pdf/rbgg/v15n1/10.pdf

30. Gonçalves LHT, Costa MAM, Martins MM, Nassar SM, Zunino R. The family dynamics of elder elderly in the context of Porto, Portugal. Rev Latino-Am Enfermagem [Internet]. 2011 [cited 2016 May 15];19(3):458-66. Available from: http://www.scielo.br/ pdf/rlae/v19n3/03.pdf 